
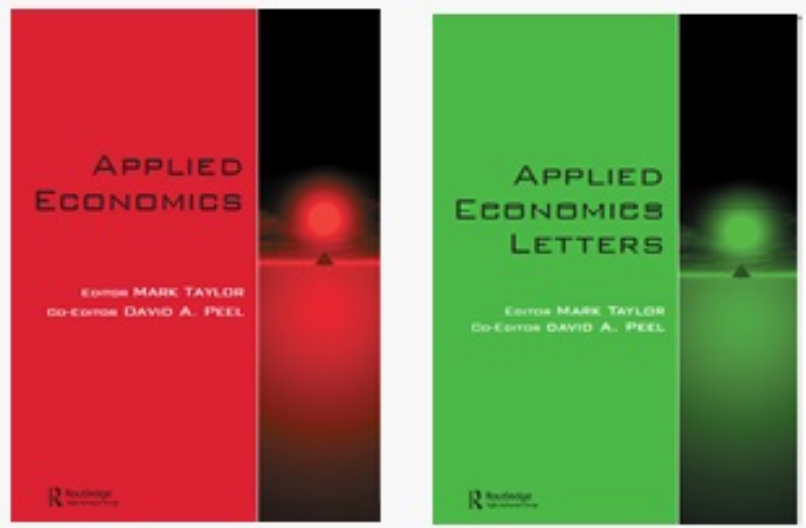

\title{
Investigating the impact of auto loans on unemployment: The US experience
}

\begin{tabular}{|r|l|}
\hline Journal: & Applied Economics \\
\hline Manuscript ID & APE-2020-0302 \\
\hline Journal Selection: & Applied Economics incorporating Applied Financial Economics \\
\hline Date Submitted by the \\
Author: & 18 -Apr-2020 \\
\hline Complete List of Authors: & $\begin{array}{l}\text { Apergis, Nicholas; University of Derby, } \\
\text { Apergis, Emmanuel; University of Huddersfield } \\
\text { Young, Weiwei; University of Derby }\end{array}$ \\
\hline JEL Code: & $\begin{array}{l}\text { E24 - Employment|Unemployment|Wages < E2 - Consumption, Saving, } \\
\text { Monetary Economics, E40 - General < E4 - Money and Interest Rates < E } \\
\text { - Macroeconomics and Monetary Economics }\end{array}$ \\
\hline Keywords: & Auto loans, Unemployment, US, ARDL modelling \\
\hline
\end{tabular}


Investigating the impact of auto loans on unemployment: The US experience

Nicholas Apergis (Corresponding Author)

University of Derby

n.apergis@,derby.ac.uk

Emmanuel Apergis

University of Huddersfield

e.apergis@hud.ac.uk

Weiwei Young

University of Derby

w.young@derby.ac.uk 


\title{
Investigating the Impact of Auto Loans on Unemployment: The US Experience
}

\begin{abstract}
This paper explores the impact of automobile loan debt on US unemployment. Individuals with heterogeneous economic positions deem automobiles as important durable goods for unemployment exit and expected wage increases. The methodological approach makes use of an Autoregressive Distributed Lag (ARDL) Bound Testing modelling approach to document a negative and significant relationship between auto loans and unemployment. The results survive certain robustness tests, while they seem to confirm certain theoretical arguments posed in the literature, such as that levered households suffer from a 'debt overhang' problem that distorts their preferences, making them demand high wages, and the 'vacancy-posting' effect which implies that high household debt leads to high unemployment. The findings seem to provide significant recommendations to monetary policy makers on strengthening the banking services industry, providing an alternative to monetary policy for labour market intervention.
\end{abstract}

KEYWORDS: auto loans; unemployment; US

JEL CLASSIFICATION: E40; E24

\section{Introduction}

It has been twelve years since the last global financial crisis, which caused a recession for the global economies. Although the effects of this crisis event have been fading out, over the last years, a lot has changed, especially in the consumer credit markets. Mortgages, which drew considerable attention during the last financial crisis, have been slowly tightening and, recently, 
recorded a $1.4 \%$ decrease over the last ten years; by contrast, the auto loan credit markets have presented a rising trend, displaying a 61.1\% increase since 2008 (Table 1 and Figure 1).

\section{[Insert Table 1 and Figure 1 about here]}

Three main reasons are displayed in this picture. First, after the 2008 financial crisis, millions of consumers were coping with low and irregular incomes, while the U.S. economy shed over eight million jobs. At the same time, $\mathrm{Ng}$ and Wright (2013) provide evidence that increases in leverage prior to the crisis were more pronounced for households than for firms, while Mian and Sufi (2014) highlight that the U.S. counties that had the most highly levered households, they also experienced the sharpest drops in employment.

The growth of loans was fuelled in part by borrowers with reduced credit history borrowing to purchase vehicles (Adams et al., 2009). The connection of automobile mobility with social inequality is not new (Kain, 1968; Delbosc and Currie, 2012; Walks, 2018; Curl et al., 2018), which might result to physical exclusion, economic exclusion and leisure exclusion. Regardless of the income group households belong, they perceive automobiles as an exit window from unemployment or for gaining higher wages, thus heating up demand, leading auto loans to soar up. Moreover, the low-interest rates after the crisis aiming to bounce up the economy provided cheap and easy access to credit for the majority of consumers and other prospective borrowers, while when the financial crisis was over, it found many car manufacturers struggling to improve their sales due to a sluggish demand (Figure 2). As a result, their marketing strategies changed and offered many incentives to car dealers and auto finance companies to recover their sales ${ }^{1}$. Effective marketing strategies and aggressive

\footnotetext{
${ }^{1}$ Sales financing companies started as accounts receivable financing companies and then moved into instalment financing. They were purchasing instalment paper from retailers and financing retail inventories. According to Phelps (1952), it is the sale finance companies that boomed automotive companies in the 1920s with the mass distribution of automobiles dependent on wholesale and retail financing. Famous brands, such as Toyota and General Electric, tend to rely on nonbank lenders, i.e. Southeast Toyota Finance Company, Toyota Motor Credit Company (Kaisha, 1988), General Motors Acceptance Corporation (Sloan, 1964; Charles et al., 2008), and Ford
} 
advertisement helped carmakers to survive international competition, but this involved a lot of hidden costs and risks. Because of the fierce competition, some lenders also relaxed their loan terms and increased their exposure (McLannahan, 2018).

\section{[Insert Figure 2 about here]}

Tight regulations put in place after the crisis, have made it harder for people to get a mortgage, but most of the rules do not seem to apply to auto finance companies. Statistics suggests that delinquency rates for mortgages have been steadily falling, but auto loan rates have been rising (Figure 3). There has been a rising number of car buyers showing signs of struggling to make auto loan payments over the recent years (Long, 2017; Wack, 2017). One of the releases by the Federal Reserve Bank of New York (Bourassa, 2018) highlights the rising auto loan balances, where about seven million Americans are 90 days or more behind on their auto loan payments, with especially younger borrowers struggling with auto debt delinquencies. The auto loan delinquencies are an accurate measure of financial strains and can truly reflect the financial difficulties experienced by consumers.

\section{[Insert Figure 3 about here]}

What will make it even worse is the continuous rising trends of the Fed interest rates; if this trend continues, it will put auto finance companies under severe strain to pay back their loans. The FED is expected to keep interest rates between 2.25\% and 2.5\% (Condon and Matthews, 2019), which will put a strain on borrowers meeting their obligations. As the ongoing issue of growing auto loan debt and delinquency rates go, this may drag down consumers' repayments with a subsequent impact on the US economy. This development motivated us looking more closely into the auto loan market and the direction it its impact on unemployment. For most

Motor Credit Company (Charles et al., 2008). Non-bank financing institutions have been the financing arms of the major automobile manufacturers in the U.S. for automobile credit. 
Americans, automobiles are the second largest asset after their residence. Since loans mainly finance the majority of auto purchases, auto loans are debt for the American families, making up a sizeable portion of their credit institutions' portfolios (Wu et al., 2018). Despite the importance of auto loans to both consumers and banking institutions, a large number of studies remains focused on mortgages and the real estate market, with very little attention on the surfacing auto loan issue. By taking into consideration the economic significance of the auto loan market for the US economy and in specific towards the automobile industry, it is the right time to zoom in and examine the impact of the auto loan market on the US economy. As there has been very little work examining the auto loan market (White and Munger, 1971; Attanasio et al., 2000; Mannering et al., 2002; Heitfield and Sabarwal, 2004; Wu et al., 2018), this study attempts to contribute to this relevant strand of the literature by adding fresh evidence. Hence, it explores the role of auto loans for the course of the real economy in the US and more specifically, its impact on unemployment rates. The literature has signified the fact that the worst employment slumps usually follow substantial expansions of the household debt. According to $\mathrm{Ng}$ and Wright (2013), increases in leverage prior to the Great Recession was more pronounced for households than for firms, while Mian and Sufi (2014) highlight that the US counties with the highest levered households have the sharpest drops in employment. As a matter of fact, the link between household debt increases in unemployment, followed by slow recoveries in the labour markets is commonplace in recessions associated with financial crises (Schularick and Taylor, 2012). Therefore, it is worth exploring how potential difficulties faced by auto loan receivers to repay their loans are associated with their ability to find a job or to maintain the current one, thus, potentially contributing to a rising unemployment rate.

The theoretical background behind the empirical investigation of our research goal is clearly associated with a central mechanism that relies on a two-way bridge between labour and credit markets. The presence of auto-loans debt on the households' balance sheets seems 
to distort their preferences when they search for jobs. This type of distortions induces them to search inefficiently for high-wage jobs, while at the same time competitive firms respond to households' behaviour by posting higher wages; however, as a result, firms can only afford to post lesser job vacancies, leading to higher unemployment figures. Overall, the debt-induced distortion of the labour market search seems to be a significant channel through which increased levels of household debt amplify employment slumps. As a result, higher unemployment resulting from household debt elevates default rates, while both households and banks fail to internalise this negative labour-market-driven externality of increasing consumer credit (auto-loans), leading to excessive lending by households. Based on this discussion, the paper is closely associated with the literature on the broad credit channel, which considers the impact of monetary policy on the balance sheets of firms and households and also includes the financial accelerator concept by Bernanke and Gertler (1995). In the financial accelerator framework, monetary policy can affect the balance sheet condition of borrowers, which in turn affects the willingness of banks to lend to them. Bernanke (2007) and Disyatat (2011) also extend the financial accelerator framework of Bernanke and Gertler (1995) to banks' own balance sheets, linking their funding costs to their financial health. The key mechanism in his model is that banks' financial strength affects the spread they charge on loans to firms, and that this is affected by changes in the policy rate.

The paper is linked to individual pieces of work in the literature which investigate the interaction between credit and labour markets. For instance, Acemoglu (2001) provides supportive evidence that failures of credit markets to provide adequate funds to socially valuable projects lead to higher unemployment, a fact that clearly explains high unemployment figures in the European case, while Adams et al. (2009) document that automobile demand in the US increases sharply during the rebate season, while household default rates rise with loan size, indicating the possible desirability of loan caps. Buera et al. (2014) present a theoretical 
model where credit crunches lead to significant drops in employment for the case of small and young firms, and a lesser drop for large and old firms. Furthermore, our work is associated with the strand of the literature associated with households' limited liabilities in a directed search framework (Moen, 1997). Studies in this literature embed household credit markets in search models of the labour market (Bethune et al., 2015; Kehoe et al., 2013). However, these works focus on the expansion of lending in the boom period and the decrease in credit availability in the contraction, and not on the impact of debt on household balance sheets on certain macroeconomic aggregates, such as unemployment, which is a fact explored by our study.

The remainder of the paper is organised as follows. Section II discusses the methodology implemented for extracting the main findings, while Section III describes the data variables used for the estimations and proceeds with outlining the literature behind the specific variables. Section IV presents the empirical results, while Section V concludes.

\section{Methodology}

This section specifies an econometric model that allows examining the effects of auto loans on the unemployment rate. The following equation describes the model specification that shows the determinants of unemployment, with auto loans entering as the primary control variable of interest:

$$
\begin{aligned}
& \text { Unemployment } \text { Rate }_{t} \\
& =b_{0}+b_{1} \text { Output Gap } t+b_{2} \text { Corporate Taxes }_{t}+b_{3} \text { TFP }_{t}+b_{4}\left(\frac{\text { Auto Loans }}{\text { Total Loans }}\right)_{t} \\
& +b_{5} \mathrm{FDI}_{t}+b_{6}(\text { Social Security Contributions })_{t}+b_{7}( \\
& \text { Social Security Benefits })_{t}+b_{8} \text { Population }_{t}+b_{9}(\text { Terms of Trade })_{t}+b_{10}( \\
& \text { Real Rate })_{t}+b_{11}(\text { Labour Cost })_{t}+b_{12} C P I_{t}+u_{t}
\end{aligned}
$$

The role of loans is a vital credit channel crucial for monetary transmissions. Loans are provided by the banking sector to stimulate liquidity for households and firms, thus, fulfilling 
the essential function of the financial system (Han, 2009). The financial institutions, when healthy, are financing investments and are stimulating productivity expansion by providing convenient and cheap financing with an immediate or indirect impact to the formation of new employment (Bernanke and Blinder, 1992; Pojatina, 2008). Higher credit volumes by the banking sector lead to either increased investment or increased consumption expenditures and, hence, the employment ratio is anticipated to increase. Producers expect that consumers will increase their consumption, and for that reason, they are calibrating their production lines in line with consumer behaviour. When borrowers can pump consumer loans, their household disposable income is increasing. We can quickly expect that consumption expenditures will follow suit an increase. This encourages firms to produce higher volumes of finished products, where much higher volumes requiring higher investments in equipment and storage space. More equipment and more space demand more labour (Pagano and Pica, 2012). By contrast, unemployment levels increase when the banking sector fails to operate efficiently (Ordine and Rose, 2008). Disruptions in the credit market are reflected negatively on total economic activities, as well as on employment (Wasmer and Weil, 2004). Higher credit volumes by the banking sector should be a policy proposal fighting against unemployment because loans have a potential to stimulate aggregate demand, to encourage investments and to generate new employment opportunities (Saint-Paul, 2008).

In terms of the other potential control drivers of unemployment, economic theory and past empirical studies have identified some useful determinants. The presence of the GDP output gap is highly important since it captures potential demand-side effects. It also conveys the theoretical framework associated with Okun's law (1962), which analyses the relationship between unemployment and output growth. The central hypothesis behind this link is that there exists a significant negative relationship between output and unemployment, where an increase in output above its potential value leads to lower unemployment rates. The hypothesis has been 
extensively studies in the relevant literature. Among many studies, Pinho and de Pinho (2015) explore this relationship in the case of the Portuguese economy. Their evidence, however, provides different results by region, recommending the implementation of different public policies for each location given their idiosyncratic characteristics, while Guisinger, et al. (2018) document that US states are not only characterised by substantial differences in terms of their labour market structures, due to differences in the level of job protection, minimum wage laws, labour union power, and the demographics, but also certain labour indicators, as well as labour market flexibility have a significant effect on the Okun's relationship.

Several empirical studies have found that corporate taxes increase unemployment rates (Nickell, 1997; Belot and Van Ours, 2004), although other studies are less conclusive (Scarpetta, 1996; Elmeskov et al., 1998; Nunziata, 2002; DiTella and Macculloch, 2005). Several explored studies report a positive relationship between corporate taxes and unemployment rates (Belot and Van Ours, 2004; Nickell, 1997). Daveri and Tabellini (2000) find a strong impact in countries with powerful trade unions and a low or a medium degree of centralisation (coordination) of the wage bargaining process, while Elmeskov et al. (1998) find notably significant effects in countries with intermediate centralisation (coordination). These studies conclude that trade unions push for higher wages in order to compensate for higher taxes.

Moreover, the terms of trade are defined as the ratio of imports to output multiplied by the logarithm of their relative prices: $\frac{M}{Y} \times \log \left(\frac{P M}{P Y}\right)$. This is interpreted in such a way, as its growth rate is the change in the relative price of imports weighted by the share of imports in GDP. The widening of the wedge between consumer and producer prices, a rise in the relative price of imports should increase wage pressures and, ultimately, unemployment (Layard et al., 1991). Furthermore, real interest rates are defined as the difference between the 10 -year 
nominal government bond yield and the annual GDP price inflation, are also considered as an additional driver of unemployment. A rise in real interest rates tends to reduce firstly, capital accumulation and secondly, labour productivity with significant implications on labour demand (at a given wage level) (Blanchard, 1999, 2000). Another variable we include in the modelling specification is unemployment benefits. High unemployment benefits available for a relatively long duration can have adverse effects on labour market performance (Scarpetta, 1996; Nickell, 1998; Elmeskov et al., 1998; Nunziata, 2002). Benefits may raise unemployment via two mechanisms: i) by lowering the job-search intensity of the unemployed, and ii) by reducing the economic cost of unemployment.

The model specification in (1) also includes TFP as an explanatory variable of unemployment. The literature has extensively looked at the relation between TFP and unemployment in a theoretical framework, concluding that the impact of TFP on employment is ambiguous (Aghion and Howitt, 1994; Phelps, 1994; Mortensen and Pissarides, 1998; Ball and Moffit, 2002); moreover, these authors argue that the effects of growth on employment are not only unambiguous but also temporary. By contrast, Shimer (2003) and Hall (2003) illustrate the presence of a strong positive impact of TFP on employment.

Holister and Goldstein (1994) conclude that population size also affects unemployment due to changes in the supply of labour force. Based on their findings, the impact turns out to be positive. Similar results are provided by Rafiq et al. (2010). Eita et al. (2010) provide supportive evidence that changes in the cost of labour positively affect unemployment. Corroborating the previous results, Nunnenkap et al. (2007) document that a significant relationship between FDI and unemployment is observed. Zaman et al. (2011) and Aqil et al. (2014) provide supportive evidence of a strong relationship between inflation and unemployment, thus, justifying the presence of a Philips curve. Moreover, the inclusion of inflation explicitly considers potential effects in monetary and/or fiscal policy. 
The empirical analysis applies the Autoregressive Distributed Lags (ARDL) cointegration methodology (Pesaran et al., 2001), to provide both long- and short-run estimates between the two primary variables considered, i.e. unemployment and auto loans. The primary advantage of the ARDL methodology approach is that it does not require an integrated series of the same order. The modelling methodology in the ARDL bounds test framework yields the following error correction equations:

$$
\begin{aligned}
& \text { p } \quad \text { q } \\
& \Delta \mathrm{y}_{\mathrm{t}}=\mathrm{a}_{0}+\mathrm{a}_{1} \mathrm{t}+\sum_{\mathrm{a}_{2 \mathrm{i}}} \Delta \mathrm{y}_{\mathrm{t}-\mathrm{i}}+\sum_{\mathrm{a}_{3 \mathrm{i}}} \Delta \mathrm{z}_{\mathrm{t}-\mathrm{i}}+\mathrm{a}_{4} \mathrm{y}_{\mathrm{t}-1}+\mathrm{a}_{5} \mathrm{z}_{\mathrm{t}-1}+\mathrm{u}_{\mathrm{t}} \\
& \mathrm{i}=1 \quad \mathrm{i}=0
\end{aligned}
$$

where y represents unemployment, while $\mathrm{z}$ denotes a vector of the control variables that affect unemployment, and described by Equation (1). The parameters $\alpha_{2 \mathrm{i}}$ and $\mathrm{a}_{3 \mathrm{i}}$ represent the shortrun dynamic coefficients, while those as $\mathrm{a}_{4}$ and $\mathrm{a}_{5}$ are the long-run coefficients. Finally, $\mathrm{u}$ describes a white noise process. If the presence of cointegration is confirmed, then the longand the short-run models are estimated and both long- and short-run estimates are derived, which is the ARDL equivalent of the Unrestricted Error Correction model. Cointegration, in the ARDL bounds test approach, is examined under the following null hypothesis set up: $\mathrm{H}_{0}$ : $a_{1}=a_{2}=\ldots=a_{n}=0$. The presence of cointegration is validated if the null hypothesis is rejected. In that case, the next step proceeds with the establishment of the error correction mechanism (ECM). Evidence of cointegration implies that there is a long-run relationship between the variables and their connection is not a short-lived case, but a more permanent one, which can be recovered every time there is a disturbance.

\section{Data}

In terms of the unemployment equation, unemployment is measured through the unemployment rate. Quarterly data are available through the Bureau of Labour Statistics, 
spanning the period 2002:1-2018:4, totalling in 68 available observations. These data are restricted to people 16 years of age and older and are not on active duty in the Armed Forces.

The primary determinant of unemployment is auto loans. The analysis employs the auto loans ratio measured in terms of the motor vehicle loans owned and securitised to total loans, with data coming from Datastream. The output gap is determined by applying the HodrickPrescott (HP) filter to the real GDP (Hodrick and Prescott, 1997), with data on real GDP also coming from Datastream. Data on corporate tax rates are in the form of effective marginal tax rates. Following Heider and Ljungqvist (2015), the analysis focuses on changes in the marginal tax rate since this approach is appropriate as US states. Data on corporate taxes are obtained from the Bureau of Economic Analysis (BEA). Next, data on prices of imports and exports are sourced from the COMTRADE database. Data on nominal 10-year bond rates and inflation come from Datastream, while for those of unemployment benefits, in the U.S., no large data source measuring nonemployment spells, i.e., the duration between jobs, is currently available, which makes it hard to get direct data on those benefits. Hence, studies have either used measures of self-reported unemployment duration from the Current Population Survey (CPS), or duration of unemployment benefit receipts from administrative records. Given that many unemployed individuals exhaust those benefits before finding a job, the CPS-based measure is in principle preferable, although the literature has provided certain shortcomings, i.e. the CPS measure is noisy and does not capture workers' total length of non-employment, which may include periods in which workers do not declare themselves unemployed (Schmieder et al., 2012). Next, the analysis measures TFP by making use of a conventional growth accounting framework, i.e. the residuals from an aggregate production function, a Cobb-Douglas production function, with data from employment (measured by hours of work) and capital formation obtained from the BEA. Moreover, population data come from the Penn World Tables, Version 9.1. Labour cost is proxied by wages, defined as nonfarm business sector real 
compensation per hour, with data coming from the Federal Reserve Bank of St. Louis. Inflation is measured from the Consumer Price Index, with data being sourced from Datastream. The CPI-based inflation rate is calculated as the quarterly year-on-year percentage change: $\left\{\ln \left(\mathrm{P}_{\mathrm{t}}\right)-\right.$ $\left.\ln \left(\mathrm{P}_{\mathrm{t}-4}\right)\right\} \times 100$, where $\mathrm{P}$ is the CPI-index. Finally, FDI data depict flows in capital received from a foreign direct investor, and consist of three components, equity capital, reinvested earnings, and inter-company loans. Data come from the UNCTAD database. Table 2 reports a number of descriptive statistics.

\section{[Insert Table 2 about here]}

\section{Empirical analysis}

The first part of the empirical analysis investigates the presence of stationarity across all variables included in Equation (1). Table 3 reports the results of unit root tests, thus allowing us testing for the integration order of our time series. The results of the General Least Squared Dickey-Fuller test, recommended by Elliott et al. (1996), illustrate the presence of a unit root in the levels across the majority of variables under consideration. The unit root is disappeared when the first differences are implemented. This does not hold for the cases of TFP and the output gap for which stationarity is established early in their levels.

\section{[Insert Table 3 about here]}

In the next step of the empirical analysis, we test for the presence of a long-run estimation between unemployment and its determinants, described in Equation (1), while in the second step if cointegration is confirmed, the analysis proceeds to estimate the short-run relationship using an error correction model method. The results from the first step, the Bounds F-test for cointegration, are reported in Table 4, which document that unemployment is cointegrated with its associated determinants. 


\section{[Insert Table 4 about here]}

Based on the above cointegration findings, Table 5 reports the long-run estimates. They indicate that in terms of the unemployment equation, the long-run estimates illustrate that auto loans lead to statistically significant lower unemployment; at the same time, FDI inflows exert a negative impact on unemployment, with similar results being obtained from TFP, the terms of trade, and the inflation rate. By contrast, the real 10-year interest rate, labour costs, corporate taxes, population, the output gap, and social security benefits exert a positive effect on the unemployment rate. Table 6 repeats the long-run ARDL results, but this time the output gap is determined through the band pass filter developed by Baxter and King (1995), while an alternative measure of inflation is used, calculated as the percentage changes for the GDPdeflator. The implied GDP-deflator is calculated based on the ratio of the nominal GDP and the real GDP in chained 2010 dollars. Data on this measure of the price index are sourced from Datastream. The results confirm those originally reported in Table 5 providing evidence on the negative association between auto loans and unemployment. Finally, Table 7 presents the short-run ARDL results. They clearly indicate that the selected ARDL model fits well as indicated by the diagnostic tests; in particular, the model is free from serial correlation, heteroscedasticity, and functional misspecification.

\section{[Insert Tables 5, 6 and 7 about here]}

These findings connect to a large body of papers that focus on the relationship between financial markets and the real economy. In particular, Claessens et al. $(2009,2012)$ and Mendoza and Terrones (2012) emphasise the importance of credit in shaping business cycle fluctuations. A series of papers demonstrate that financial crises can be regarded as credit booms went bust (Taylor, 2012a; 2012b; Schularick and Taylor, 2012). Related works are mainly based on the seminal papers by Bernanke and Gertler (1989), Bernanke et al. (1996), 
and Bernanke et al. (1999), which explain how the financial market could amplify and propagate shocks, that originate in other sectors, to the real economy through an accelerator mechanism. The underlying research suggests that developments in the financial sector can significantly deteriorate labour market performance through restricting investment and firmentry (Acemoglu, 2001; Wasmer and Weil, 2004; Dromel et al., 2010). Petrosky-Nadeau and Wasmer (2013) show that credit imperfections aggravate the negative effect of labour market frictions on unemployment. Moreover, another credit channel relies on the hypothesis that shocks, which arise in the financial sector, can translate directly into the real economy. Quadrini (2011) proposes the mechanism of asset bubbles which can generate asset price movements that affect the business cycle through the tightening of the borrowing constraints. In addition, Jermann and Quadrini (2012) argue that financial shocks are transmitted into the real economy through the demand for labour. They explore the macroeconomic effects of disruptions in the financial sector and demonstrate that credit shocks have played an essential role in capturing the dynamics of labour and output in the US economy over time. Finally, Bentolila et al. (2017) and Chodorow-Reich (2014) assess the impact of large credit supply shocks on firm-level employment for Spain and the U.S. These studies show that unanticipated reductions in bank lending have a sizable effect on employment outcomes.

The analysis offers a clear policy direction against unemployment, and policies, such as usually restrictions can lead to adverse effects on loan contracts. Auto dealers are contracting around state usury limits by financing their customers and pricing default risk through the mark-up rather than through the interest rate (Melzer and Schroeder, 2017). Therefore, the exclusion we talked before is the result of captive financing for a large share of auto purchases since borrowers depending on their credit rating facing different loan terms, such as differences in loan maturity, more prominent collateral or the loan amount per se. 


\section{Conclusion}

There is a growing concern about the rising debt balance of automobile loans in the US. In order to explore this phenomenon, this paper investigated the role of US auto loans in aggregate unemployment, using the methodology of the ARDL Bound Test modelling. The empirical results provided clear evidence of a negative and statistically association between them. Although specific bank variables have not been used in the empirical analysis, the findings seem to have substantial implications for the role of bank capital requirements in promoting employment. More specifically, regulators must ensure the presence of a wellcapitalized banking system that can not only contribute to the reduction in financial fragility but also it can foster reductions in unemployment.

\section{References}

Acemoglu, D. 2001. “Credit Market Imperfections and Persistent Unemployment.” European Economic Review 45: 665-679.

Adams, W., Einav, L., and Levin, J. 2009. "Liquidity Constraints and Imperfect Information in Subprime Lending." American Economic Review 99: 49-84.

Aghion, P., and Howitt, P. 1994. "Growth and Unemployment.” Review of Economic Studies 61: 477-494.

Aqil, M., Ali, Q.M., and Seemab, Q. 2014. "Determinants of Unemployment in Pakistan." International Journal of Physical and Social Sciences, 4: 676-682.

Ball, L., and Moffitt, R. 2002. "Productivity Growth and the Phillips Curve." In Krueger, A.B., and Solow, R. (Eds.) The Roaring Nineties: Can Full Employment Be Sustained? Russell Sage Foundation, New York.

Baxter, M., and King, K. 1995. "Measuring Business Cycles: Approximate Band-Pass Filters for Economic Time Series.” NBER Working Paper, No. 5022. Cambridge. 
Belot, M., and Van Ours, J. 2001. "Unemployment and Labor Market Institutions: An Empirical Analysis.” Journal of the Japanese and International Economy 15: 403-418.

Bentolila, S., Jansen, M., Jimenez, G., and Ruano, S. 2017. “When Credit Dries Up: Job Losses in the Great Recession.” Journal of the European Economic Association 16: 650-695.

Bernanke, B.S. 2007, "The Financial Accelerator and the Credit Channel." Speech at a conference on The Credit Channel of Monetary Policy in the Twenty-first Century, Federal Reserve Bank of Atlanta, Atlanta, Georgia.

Bernanke, B.S., and Gertler, M. 1995. "Inside the Black Box: The Credit Channel of Monetary Policy Transmission." Journal of Economic Perspectives 9: 27-48.

Bernanke, B.S., and Blinder, S.A. 1992. "The Federal Funds Rate and the Channels of Monetary Transmission.” American Economic Review 82: 901-921.

Bernanke, B.S., and Gertler, M. 1989. “Agency Costs, Net Worth, and Business Fluctuations.” American Economic Review 79: 14-31.

Bernanke, B.S., Gertler, M., and Gilchrist, S. 1996. "The Financial Accelerator and the Flight to Quality." The Review of Economics and Statistics 78: 1-15.

Bernanke, B.S., Gertler, M., and Gilchrist, S. 1999. "The Financial Accelerator in a Quantitative Business Cycle Framework.” In Taylor, J.B., and Woodford, M. (Eds.), Handbook of Macroeconomics, Volume 1, Chapter 21, Elsevier, 1341-1393.

Bethune, Z., Rocheteau, G., and Rupert, P. 2015. “Aggregate Unemployment and Household Unsecured Debt." Review of Economic Dynamics 18: 77-100.

Blanchard, O. 1999. "European Unemployment: The Role of Shocks and Institutions.” Baffi Lecture, Rome.

Blanchard, O. 2000. "The Economics of Unemployment: Shocks, Institutions and Interactions.” Lionel Robbins Lectures, London School of Economics.

Bourassa, B. 2019. "Total Household Debt Rises as 2018 Marks the Ninth Year of Annual Growth in New Auto Loans.” Federal Revere Bank of New York, Press Release, 12th Feb 2019. 
Buera, F.J., Fattal-Jaef, R., and Shin, Y. 2014. “Anatomy of a Credit Crunch: From Capital to Labor Markets.” NBER Working Paper, No. 19997, National Bureau of Economic Research, Inc.

Chodorow-Reich, G. 2014. "The Employment Effects of Credit Market Disruptions: FirmLevel Evidence from the 2008-9 Financial Crisis.” The Quarterly Journal of Economics 129: $1-59$.

Claessens, S., Kose, M.A., and Terrones, M.E. 2009. "What Happens During Recessions, Crunches and Busts?” Economic Policy 24: 653-700.

Claessens, S., Kose, M.A., and Terrones, M.E. 2012. "How do Business and Financial Cycles Interact?" Journal of International Economics 87: 178-190.

Condon, C., and Matthews, S. 2019. "Powell Downplays Tepid Inflation, Showing no Bias to Hike or Cut.” Bloomberg, $1^{\text {st }}$ May, 2019.

Coppola, G. 2019. “Auto Loan Delinquencies are the Highest since 2012.” Bloomberg, 12th Feb, 2019.

Daveri, F., and Tabellini, G. 2000. "Unemployment, Growth and Taxation in Industrial Countries." Economic Policy 15: 47-104.

Delbosc, A., and Currie, G. 2012. "Choice and Disadvantage in Low-Car Ownership Households." Transport Policy 23: 8-14.

Disyatat, P. 2011. "The Bank Lending Channel Revisited." Journal of Money, Credit and Banking 43: 711-734.

Di Tella, R., and Macculloch, R. 2005. "The Consequences of Labor Market Flexibility: Panel Evidence Based on Survey Data.” European Economic Review 49: 1225-1259.

Dromel, N.L., Kolakez, E., and Lehmann, E. 2010. "Credit Constraints and the Persistence of Unemployment." Labour Economics 17: 823-834.

Eita, J., Hmibia, N., and Ashipala, J.M. 2010. "Determinants of Unemployment in Namibia." International Journal of Business and Market 5: 92-104.

Elliott, G., Rothenberg, T.J., and Stock, J.H. 1996. "Efficient Tests for an Autoregressive Unit Root." Econometrica 64: 813-836. 
Guisinger, A.Y., Hernandez-Murillo, R., Owyang, M.T., and Sinclair, T.M. 2018. "A StateLevel Analysis of Okun's Law.” Regional Science and Urban Economics 68: 239-248.

Heider, F., and Ljungqvist, A. 2015. "As Certain as Debt and Taxes: Estimating the Tax Sensitivity of Leverage from State Tax Changes." Journal of Financial Economics 118: 684-712.

Hamburger, M.J. 1967. "Interest Rates and the Demand for Consumer Durable Goods." American Economic Review 57: 1131-1153.

Han, C.K. 2009. "Unemployment, Financial Hardship, and Savings in Individual Development Accounts." Journal of Poverty 13: 74-95.

Higashiyama, J. 2009. "State Automobile Dealer Franchise Laws: Have they Become the Proverbial Snake in the Grass?" SSRN, No. 1394877.

Hodrick, R.J., and Prescott, E.C. 1997. "Postwar U.S. Business Cycles: An Empirical Investigation.” Journal of Money, Credit and Banking 29: 1-16.

Holister, R., and Goldstein, M. 1994. "Reforming Labour Markets in the Nearest East." Report, International Center for Economic Growth.

Household Debt, Credit Report (Q4:2018). Centre for Microeconomics. Federal Reserve Bank of New York.

Jermann, U., and Quadrini, V. 2012. "Macroeconomic Effects of Financial Shocks." American Economic Review 102: 238-271.

Johnson, D.S., Parker, J.A., and Souleles, N.S. 2006. "Household Expenditure and the Income Tax Rebates of 2001.”American Economic Review 96: 1589-1610.

Kain, J.F. 1968. "Housing Segregation, Negro Employment, and Metropolitan Centralization." The Quarterly Journal of Economics 82: 175-197.

Kaisha, J. 1988. "Toyota: A History of the First 50 Years." Toyota City: Toyota Motor Corporation.

Kehoe, P., Midrigan, V., and Pastorino, E. 2013. "Debt Constraints and Unemployment." Working Paper, University of Minnesota.

Layard, R., Nickell, S., and Jackman, R. 1991. Unemployment: Macroeconomic Performance and the Labour Market. Oxford University Press, Oxford. 
Long, H. 2017. "6.3 Million Americans are 90 Days Late on their Auto Loan Payments." Washington Post, 14 Nov. 2017.

Mannering, F., Winston, C., and Starkey, W. 2002. "An Exploratory Analysis of Automobile Leasing by US Households." Journal of Urban Economics 52: 154-176.

Mclannahan, B. 2018. "US Subprime Auto Loan Bears Will Have their Day in Wake of Mass Expansion.” The Financial Times, Apr. 28:2018, Business News: 12.

Melzer, B., and Scroeder, A. 2017. "Loan Contracting in the Presence of Usury Limits: Evidence from Auto Lending.” Working Paper, No. 2017-02. Consumer Financial Protection Bureau Office of Research. Washington D.C.

Mendoza, E.G., and Terrones, M.E. 2012. “An Anatomy of Credit Booms and their Demise." NBER Working Paper, No. 18379, National Bureau of Economic Research.

Mian, A., and Sufi, A. 2014. "What Explains the 2007-2009 Drop in Employment?" Econometrica 82: 2197-2223.

Moen, E.R. 1997. “Competitive Search Equilibrium.” Journal of Political Economy 105: 385411.

Mortensen, D.T., and Pissarides, C.A. 1998. "Technological Progress, Job Creation and Job Destruction." Review of Economic Dynamics 1: 733-753.

Ng, S., and Wright, J.H. 2013. "Facts and Challenges from the Great Recession for Forecasting and Macroeconomic Modelling." Journal of Economic Literature 51: 1120-1154.

Nickell, S. 1997. "Unemployment and Labor Market Rigidities: Europe versus North America." The Journal of Economic Perspectives 11: 55-74.

Nickell, S. 1998. “Unemployment: Questions and Some Answers.” The Economic Journal 108: 802-816.

Nunnenkamp, P., and Bremont, J.E. 2007. "FDI in Mexico: An Empirical Assessment of Employment Effects.” Keil Working Paper, No.1328.

Nunziata, L. 2002. "Unemployment, Labour, Market Institutions and Shocks." Nuffield College Working Papers in Economics, No. 16. 
Okun, A.M. 1962. "Potential GNP: It is Measurement and Significance." Proceedings of the Business and Economic Statistics Section. Washington: American Statistical Association, 98-104.

Ordine, P., and Rose, G. 2008. "Local Banks Efficiency and Employment.” Labour 22: 469493.

Pagano, M., and Pica, G. 2012. "Finance and Employment." Economic Policy 27: 5-55.

Pesaran, M.H., Shin, Y.R., and Smith, R.J. 2001. "Bounds Testing Approaches to the Analysis of Level Relationships.” In: Special Issue in Honour of Sargan, J.D. Studies in Empirical Macroeconometrics, Ed. by Hendry, D.F., and Pesaran, M.H., Journal of Applied Econometrics 16: 289-326.

Petrosky-Nadeau, N., and Wasmer, E. 2013. "The Cyclical Volatility of Labor Markets Under Frictional Financial Markets.” American Economic Journal: Macroeconomics 5: 193221.

Phelps, C.W. 1952. The Role of Sale Finance Companies in the American Economy. Baltimore, MD: Commercial Credit Company.

Phelps, E.S. 1994. Structural Slumps: The Modern Equilibrium Theory of Unemployment, Interest and Assets. Cambridge, MA: Harvard University Press.

Pinho, M.M., and de Pinho, M.C. 2015. "The Relationship Between the Product and Unemployment: National and Regional Evidence in Portugal.” Revista Portuguesa de Estudos Regionais 38: 19-36.

Pojatina, K. 2008. "Credit Risk, Credit and Economic Cycles in Croatian Banking." Economic Research 21: 19-33.

Quadrini, V. 2011. "Financial Frictions in Macroeconomic Fluctuations.” Economic Quarterly 97: 209-254.

Pesaran, M.H., Shin, Y., and Smith, R. 2001. "Bounds Testing Approach to the Analysis of Level Relationships." Journal of Applied Econometrics 16: 289-326.

Rafiq, M., Ahmad, I., and Khan. Z. 2010. "Determinants of Unemployment: A Case Study of Pakistan.” Abasyn Journal of Social Services 3: 17-24. 
Saint-Paul, G. 2008. “Alternative Strategies for Fighting Unemployment: Lessons from the European Experience." World Economics 9: 35-55.

Schmieder, J.F., Von Wachter, T., and Bender, S. 2012. "The Effects of Extended Unemployment Insurance over the Business Cycle: Evidence from Regression Discontinuity Estimates over 20 Years.” Quarterly Journal of Economics 127: 701-752.

Schularick, M., and Taylor, A.M. 2012. "Credit Booms Gone Bust: Monetary Policy, Leverage Cycles, and Financial Crises, 1870-2008." American Economic Review 102: 1029-1061.

Sloan, A. 1966. My Years With General Motors. New York: Doubleday.

Taylor, A.M. 2012a. "External Imbalances and Financial Crises.” NBER Working Paper, No. 18606, National Bureau of Economic Research.

Taylor, A.M. 2012b. “The Great Leveraging.” NBER Working Paper, No. 18290, National Bureau of Economic Research.

Wack, K. 2017. “Auto Loan Delinquencies Hit Highest Level in Four Years.” American Banker 7 Apr. 2017.

Walks, A. 2018. "Driving the Poor into Debt? Automobile Loans, Transport Disadvantage, and Automobile Dependence." Transport Policy 66: 137-149.

Wasmer, E., and Weil, P. 2004. "The Macroeconomics of Labor and Credit Market Imperfections." American Economic Review 94: 944-963.

White, J.J., and Munger, F. 1971. “Consumer Sensitivity to Interest Rates: An Empirical Study of New Car Buyers and Auto Loans.” Michigan Labor Review 69: 1207-1258.

Zaman, K., Khan, M.M., Ahmad, M., and Ikram. W. 2011. "Inflation, Unemployment and the NAIRU in Pakistan (1975-2009)." International Journal of Economics and Finance 3: 245-254. 
Table 1. Consumer Loan Changes: 2008-2018.

\begin{tabular}{cccc}
\hline Types of consumer loan & Total in 2008 (\$ trillion) & Total in 2018 (\$ trillion) & Change $(\%)$ \\
\hline Mortgage & 9.257 & 9.124 & $-1.437 \%$ \\
Auto Loan & 0.791 & 1.274 & $61.062 \%$ \\
Credit Card & 0.866 & 0.87 & $0.462 \%$ \\
Other & 0.4116 & 0.407 & $-1.118 \%$ \\
Total & 11.3256 & 11.675 & $3.085 \%$ \\
\hline
\end{tabular}

Source: New York Fed Consumer Credit Panel/Equifax 
Table 2. Descriptive Statistics.

\begin{tabular}{cccccc}
\hline Variables & Mean & SD & Min & Max & Jarque-Bera \\
\hline (Auto Loans) / (Total Loans) & 0.104 & 0.218 & 0.000 & 1.204 & $587.560[0.00]$ \\
Unemployment rate & 6.351 & 1.859 & 4.10 & 9.90 & $6.743[0.03]$ \\
FDI & $266,582.5$ & $50,185.2$ & 1,288 & 957,556 & $180.37[0.00]$ \\
TFP & -0.000 & 1.575 & -4.884 & 2.734 & $8.165[0.01]$ \\
Population & $308,618,051$ & $9,908,534$ & $293,638,158$ & $323,127,515$ & $3.946[0.13]$ \\
Terms of trade & 0.526 & 1.949 & -5.00 & 7.00 & $26.513[0.00]$ \\
Real 10-yr bond rate & 2.869 & 1.019 & 1.124 & 4.906 & $3.30[0.19]$ \\
Labour cost(logs) & 1.970 & 0.040 & 1.899 & 2.025 & $5.011[0.08]$ \\
Personal income/labour & $1,195,581.02$ & $257,232.41$ & 773,196 & $1,633,302$ & $3.334[0.19]$ \\
taxes & & & & & 16.51 \\
Social security & 10.21 & 3.49 & 4.55 & $13.687[0.00]$ \\
benefits(months) & -2.096 & 1.903 & -6.475 & 0.166 & $6.215[0.04]$ \\
Output gap & 93.191 & 7.445 & 78.60 & 105.20 & $3.524[0.17]$ \\
CPI & & & 68 & &
\end{tabular}

$\mathrm{SD}=$ standard deviation. Figures in brackets denote $\mathrm{p}$-values. 
Table 3. GLS Unit Root Tests.

\begin{tabular}{ccc}
\hline Variables & \multicolumn{2}{c}{ GLS Test } \\
\hline Auto loans/Loans & $-1.38(4)$ & $-6.18(3)^{* * *}$ \\
Unemployment rate & $-1.37(5)$ & $-6.18(3)^{* * *}$ \\
FDI & $-1.32(4)$ & $-5.99(3)^{* * *}$ \\
TFP & $-6.08(3)^{* * *}$ & - \\
Population & $-1.42(5)$ & $-6.13(4)^{* * *}$ \\
Terms of trade & $-1.33(5)$ & $-6.14(3)^{* * *}$ \\
Real 10-yr bond rate & $-1.28(4)$ & $-6.09(2)^{* * *}$ \\
Labour cost & $-1.41(6)$ & $-6.72(4)^{* * *}$ \\
Corporate taxes & $-1.44(5)$ & $-6.58(3)^{* * *}$ \\
Social security benefits & $-1.42(5)$ & $-5.84(4)^{* * *}$ \\
Output gap & $-6.18(3)^{* * *}$ & - \\
CPI & $-1.28(5)$ & $-6.93(3)^{* * *}$ \\
\hline
\end{tabular}

Rejection of the null hypothesis indicates stationarity. Lags in parentheses denote the number of lags included in the test; it was determined through the Akaike information criterion. ***: $\mathrm{p} \leq 0.01$. 
Table 4. Bounds F-Test for Cointegration-Eq. (1).

\begin{tabular}{lcc}
\hline $\begin{array}{c}\text { Dependent } \\
\text { variable }\end{array}$ & F-statistic & Lags \\
\hline Unemployment & $26.37 * * *[0.00]$ & 2 \\
\hline $\begin{array}{l}\text { Figures in brackets denote p-values. The number of lags was } \\
\text { determined through the Akaike criterion. } * * *: p \leq 0.01 .\end{array}$
\end{tabular}


Table 5. Long-Run ARDL Estimates (Output Gap is Measured Through the HP Filter and Inflation Through the CPI).

\begin{tabular}{ccc}
\hline Variable & Coefficient & $\mathrm{p}$-value \\
\hline Unemployment equation (Lags = 2) & & \\
Output gap & $0.118^{* * *}$ & 0.00 \\
Corporate taxes & $0.096^{* * *}$ & 0.01 \\
TFP & $-0.136^{* * *}$ & 0.00 \\
Auto loans/Total loans & $-0.162^{* * *}$ & 0.00 \\
FDI & $-0.114^{* * *}$ & 0.00 \\
Social security benefits & $0.057^{* *}$ & 0.03 \\
Population & $0.069^{* *}$ & 0.02 \\
Terms of trade & $-0.083^{* * *}$ & 0.00 \\
Real 10-yr bond rate & $0.114^{* * *}$ & 0.00 \\
Labour cost & $0.056^{* *}$ & 0.03 \\
CPI & $-0.142^{* * *}$ & 0.00 \\
\hline$* *: \mathrm{p} \leq 0.05 ; * * *: \mathrm{p} \leq 0.01$. & & \\
\hline
\end{tabular}


Table 6. Long-Run ARDL Estimates (Output Gap Measured Through the Band-Pass Filter and Inflation Through the GDP Deflator).

\begin{tabular}{ccc}
\hline Variable & Coefficient & $\mathrm{p}$-value \\
\hline Unemployment equation (Lags $=2)$ & & \\
Output gap & $0.107^{* * *}$ & 0.00 \\
Corporate taxes & $0.084^{* * *}$ & 0.01 \\
TFP & $-0.117^{* * *}$ & 0.00 \\
Auto loans/Total loans & $-0.155^{* * *}$ & 0.00 \\
FDI & $-0.095^{* * *}$ & 0.01 \\
Social security benefits & $0.052^{* *}$ & 0.03 \\
Population & $0.059^{* *}$ & 0.03 \\
Terms of trade & $-0.077^{* * *}$ & 0.01 \\
Real 10-yr bond rate & $0.092^{* * *}$ & 0.01 \\
Labour cost & $0.051^{* *}$ & 0.03 \\
GDP Deflator & $-0.129 * * *$ & 0.00 \\
\hline$* *: \mathrm{p} \leq 0.05 ; * * * \mathrm{p} \leq 0.01$. & & \\
\hline
\end{tabular}


Table 7. Short-Run ARDL Estimates.

\begin{tabular}{|c|c|}
\hline \multicolumn{2}{|l|}{ Unemployment equation } \\
\hline Constant & $0.012[0.88]$ \\
\hline$\Delta$ Unemployment rate $(-1)$ & $0.654 * * *[0.00]$ \\
\hline$\Delta$ auto loans $(-1)$ & $-0.164 * * *[0.00]$ \\
\hline$\Delta \mathrm{FDI}(-1)$ & $-0.126 * * *[0.00]$ \\
\hline $\operatorname{TFP}(-1)$ & $-0.119 * * *[0.00]$ \\
\hline$\Delta$ Population $(-1)$ & $0.057 *[0.06]$ \\
\hline$\Delta$ Terms of trade $(-1)$ & $-0.068 * *[0.02]$ \\
\hline$\Delta$ Real $10-y r$ bond rate $(-1)$ & $0.083 * * *[0.01]$ \\
\hline$\Delta$ Labour cost $(-1)$ & $0.055 * *[0.03]$ \\
\hline$\Delta$ Corporate taxes $(-1)$ & $0.074 * *[0.02]$ \\
\hline$\Delta$ Social security benefits $(-1)$ & $0.026 *[0.09]$ \\
\hline Output gap (-1) & $0.074 * *[0.02]$ \\
\hline CPI-Inflation(-1) & $-0.068 * *[0.02]$ \\
\hline $\mathrm{EC}_{\mathrm{UN}}(-1)$ & $-0.316 * * *[0.00]$ \\
\hline \multicolumn{2}{|l|}{ Diagnostics } \\
\hline $\mathrm{R}^{2}$-adjusted & 0.72 \\
\hline Serial Correlation & {$[0.55]$} \\
\hline Functional Form & {$[0.49]$} \\
\hline Heteroscedasticity & {$[0.64]$} \\
\hline No. of observations & 68 \\
\hline
\end{tabular}




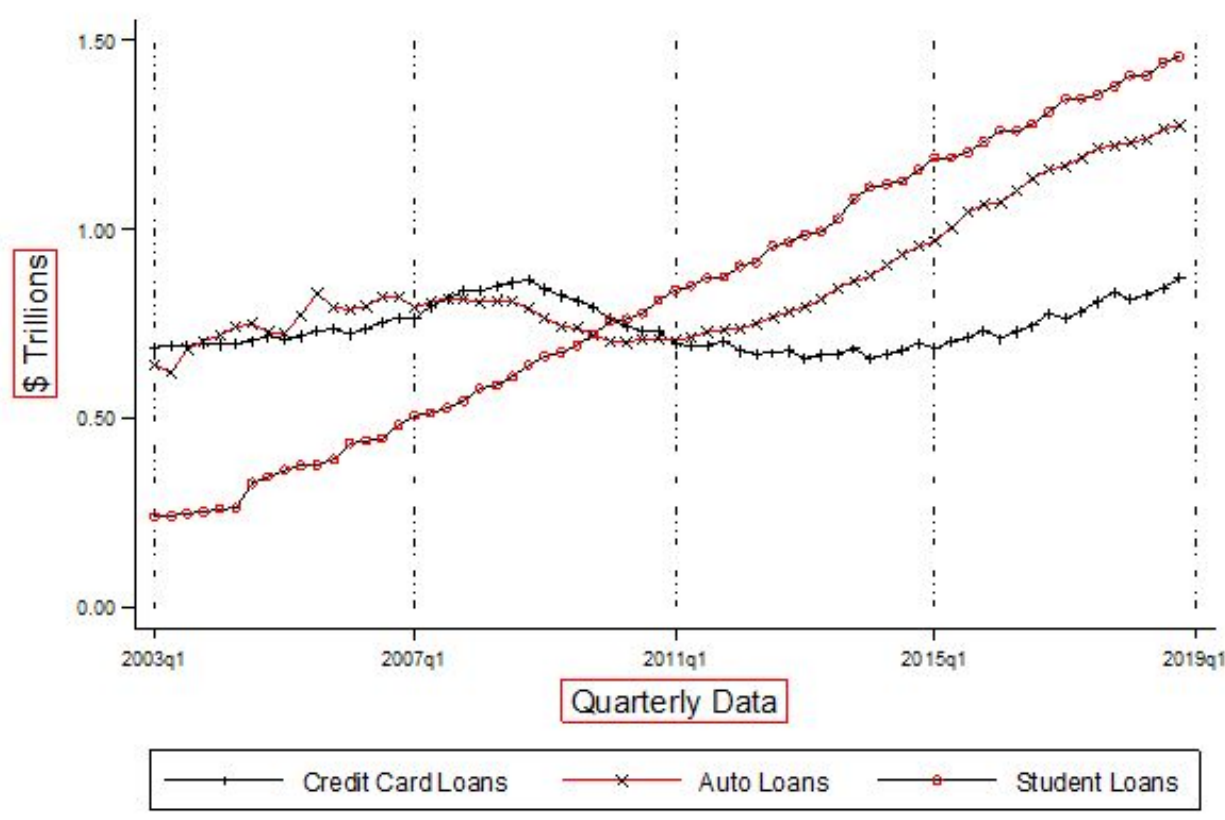

Source: New York Fed Consumer Credit Panel/Equíax

Figure 1. Total debt balance and its composition 2008-2018 (in \$trillion).

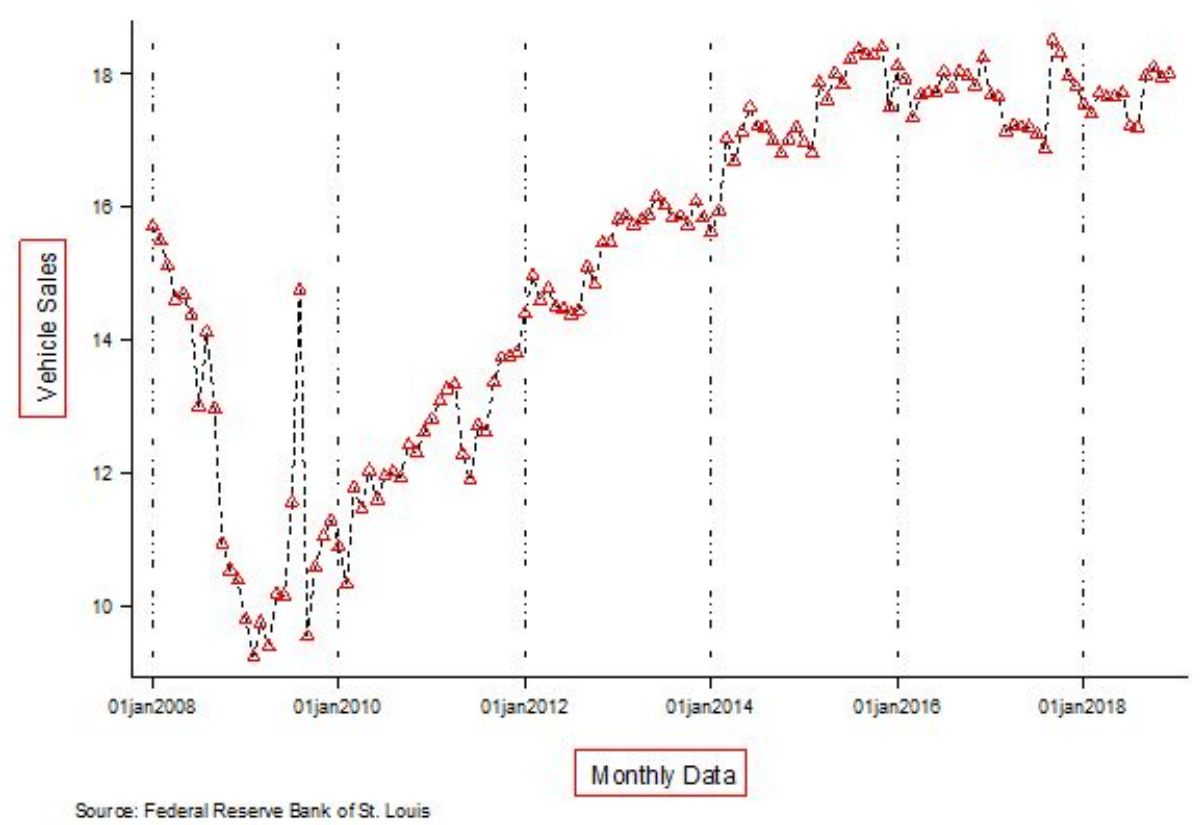

Figure 2. Total US vehicle sales volume 2008-2018 (in millions of units). 


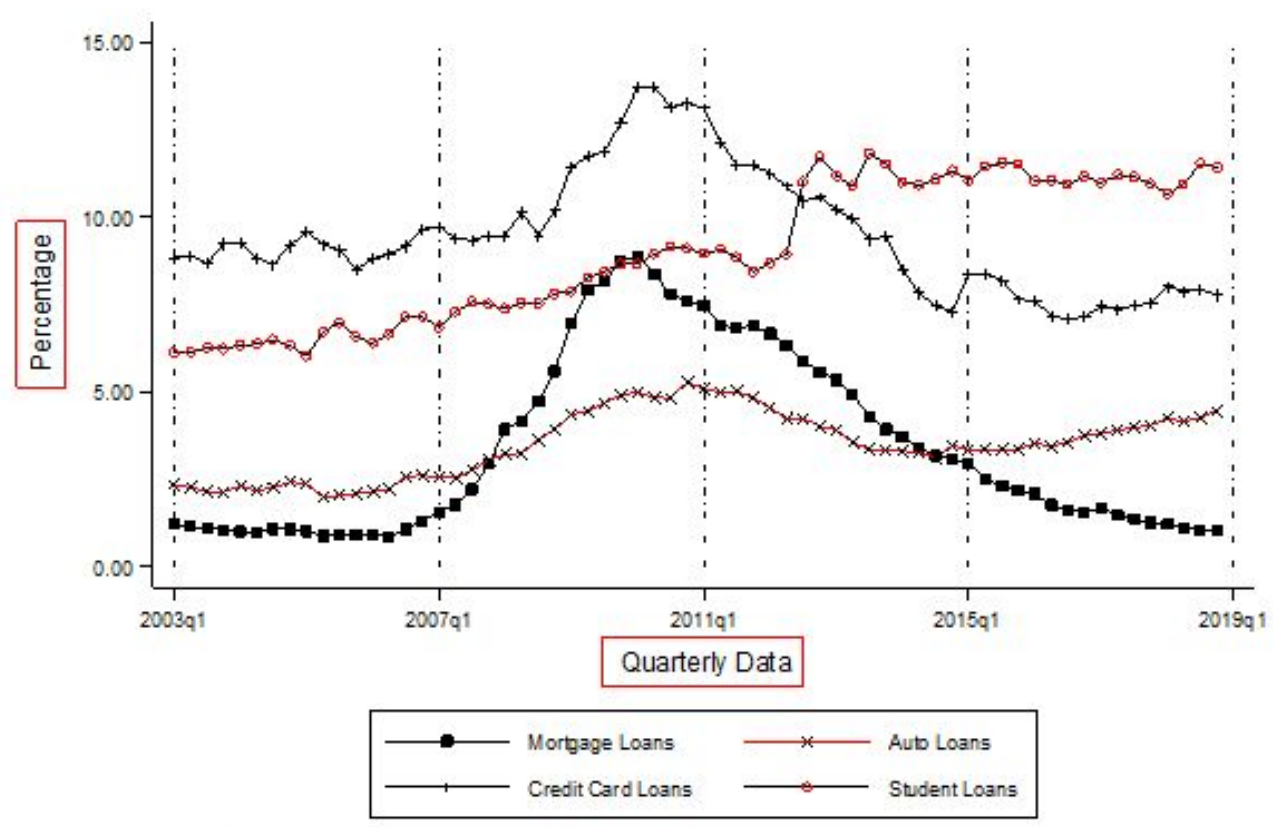

Source: New York Fed Consumer Credit PanelEquifax

Figure 3. Percent of balance 90+ days delinquent by loan type. 